\title{
Protection and Renewal Strategy of Historical Remains Landscape in Urban Reconstruction -- A case study of Guilin ring water system
}

\author{
Ping Qin ${ }^{l}$, Ying Huang ${ }^{1}$, Yu Gan²* \\ ${ }^{1}$ School of Tourism and Landscape Architecture, Guilin University of Technology, 541006 Guilin, Guangxi, China \\ ${ }^{2}$ Finance Insurance Department, Guangxi University of Finance and Economics, 530007 Nanning, China
}

\begin{abstract}
In recent years, with the rapid development of urban landscape, more and more attention has been paid to urban landscape protection. In this paper, based on the perspective of protection and renewal of historical monument landscape, a study was conducted in the Guilin ring city water system, and it was found that the water system has the problems of scattered historical relics, damaged historical spatial pattern, serious water pollution and lake waterlogging. To address these issues, this paper proposes strategies such as improving the historical space organization system, continuing the historical form and function of the city's water system, integrating historical and cultural resources, restoring the historical space pattern of the city's water system, formulating historical heritage conservation plans and continuing cultural practices. This article provides a beneficial discussion on creating an ideal environment with rich history and culture, suitable for human habitation, and shaping the region and character of the city.
\end{abstract}

\section{Introduction}

The historical relics in the city include not only the historical relics, but also the urban spatial pattern, spatial system and landscape interface, reflecting the historical features and life characteristics of different periods. The historical water system, such as natural rivers and lakes or artificial rivers, is closely related to the historical development of the city. In ancient times, it has irrigation, protection, transportation, sightseeing and other functions. It is an important infrastructure of the city and is of great significance for the formation and development of the city. Guilin is a famous historical and cultural city born of water. Its water system around the city was formed in the Song Dynasty and played an important role at that time. However, in urban rapid development, its function is gradually lost due to the problems of water system fracture and serious pollution. Therefore, the protection and renewal of the water system around the city are effective means to optimize the cityscape of Guilin. In this article, the protection and renewal strategies of historical remains in urban reconstruction are discussed by taking the water system around Guilin city as an example.

\section{The formation and existing problems of water system around Guilin City}

\subsection{The formation of water system around the city}

The water system around the city is located in the central part of Guilin city and is connected with Lijiang River and Taohua River. Gui Lake, Rong Lake, Shan Lake and Mulong Lake (also known as the four lakes) are the inner lakes in the urban centre, which are distributed from north to south around the urban centre. Lijiang River, Taohua River and four lakes constitute the water system around the city [1].

Rong Lake and Shan Lake were formed in the fourth year of Wude (621 AD) of Tang Dynasty. At that time, Rong Lake and Shan Lake, collectively known as Yangjiang River, existed as the moat of Guilin. According to historical records, during the reign of emperor Yingzong of Song Dynasty, Chaozong Canal was excavated, forming the first water system around Guilin: Lijiang River, Chaozong Canal, West Lake, Yangjiang River, and Taohuajiang River. The ring water system system in Song Dynasty is shown in Fig. 1. At the end of Nanzong period, the moat river (now Guihu Lake) was built from Shan Lake to Liuma Mountain, Laoren Mountain and Parrot Mountain to reinforce the city wall and connect with the original Chaozong Canal, making Guilin's water network more developed. After the Song Dynasty, the Chaozong Canal dried up gradually and the West Lake also reduced from $46.7 \mathrm{hm}^{2}$ in its heyday to less than $4.67 \mathrm{hm}^{2}$, which was due to the lack of protection consciousness. Thus, the water system around the city was disconnected. In recent years, along with the "two rivers and four lakes" project, Mulong Lake has been newly built, and Gui Lake, Shan Lake, Rong Lake, Lijiang River and Taohua River have been

\footnotetext{
* Corresponding author: 511087298@qq.com
} 
reconnected to form a new water system around the city [2].

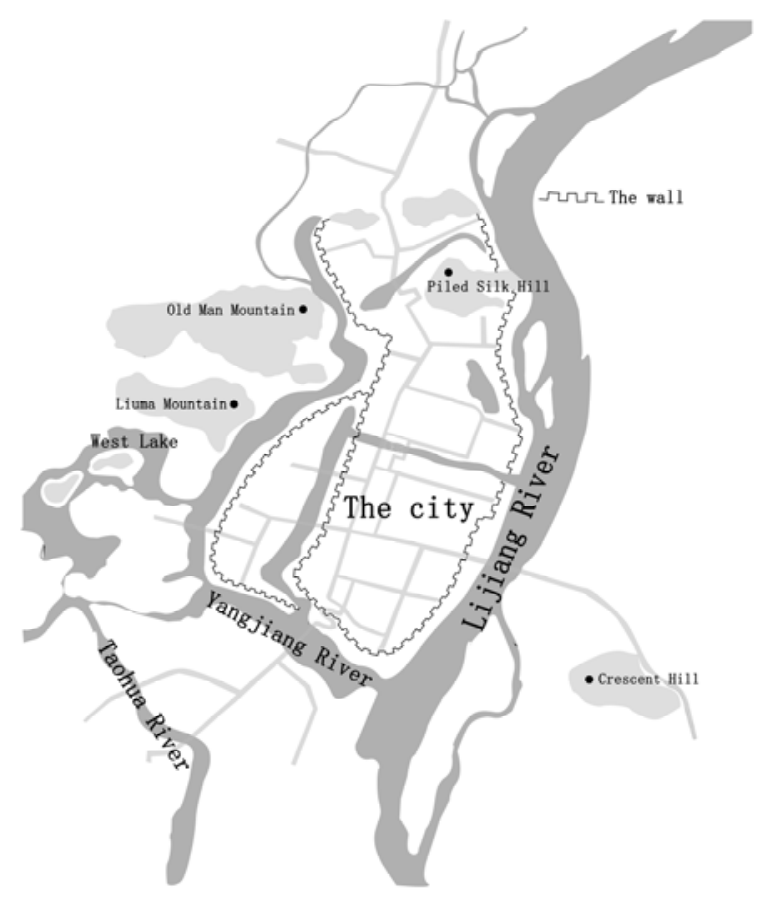

Fig. 1. The river system around the city in song Dynasty.

\subsection{Problem sorting}

\subsubsection{The problem of historical remains and historical spatial pattern of water system around the city}

In the rapid development of the city, the Chaozong Canal built in the Song Dynasty gradually dried up, and the water system around the city composed of Lijiang River, Chaozong Canal, West Lake, Yangjiang River and Taohua River was also fractured. Guilin did not form a complete water system until the construction of modern Mulong Lake. Moreover, the recognition of water system nodes is not strong, and fragmentary historical memory is not integrated. Numerous historical relics of the water system are scattered on both sides of the water system around the city. These historical and cultural resources are not integrated and suffer from a lack of systematic protection and restoration. Moreover, a large number of modern buildings have been built on both sides of the water system, which has destroyed the historical features of the ancient water system and damaged the historical spatial pattern of the ancient water system. Therefore, the landscape of ancient water system is destroyed, which makes the utilization rate of residents low. The spatial integrity is not being reflected in the surrounding water system of the city, the nodes are not recognizable, and the authenticity of life is hardly maintained.

\subsubsection{Water system problems}

The water system project around the city was first formed in the Northern Song Dynasty. It played an important role in irrigation, protection, transportation and sightseeing. In the process of urban development, the water system around the city was polluted and lost its function. In the process of urban expansion, Rong Lake, Shan Lake and Gui Lake are all surrounded by urban land, while Mulong Lake is filled and silted up in the process of urban expansion and becomes construction land. Shan Lake, Rong Lake and Gui Lake have become the rain and sewage discharge areas of the city. As a rainwater drainage area, the inner lake has accumulated a lot of organic and harmful substances. Moreover, the water is black and stinky because of the proliferation of bacteria and algae in the lake. It is incompatible with the beautiful landscape of Guilin [1]. Through the accumulation over the years, a large number of silt has been formed, which makes the ecological environment of the lake area bad, and breeding a wide variety of bacteria and fungi, which makes the water black and stink. According to the statistics in 1988, there are 43 drainage outlets near Gui Lake, Rong Lake and Shan Lake, and the sewage discharged into the lake is about $10000 t$ per day [3]. In contrast to the Song Dynasty, the functions of the circulating water system have been severely affected, in terms of irrigation, protection, transportation and tourism, as the water system is heavily polluted.

\section{Planning Strategy}

\subsection{The perfection of historical space organization system}

Ancient water systems should be conserved in a way that corresponds to Guilin's urban planning, highlighting the characteristics of Guilin's historical culture and natural landscape. It should also keep the city characteristics of mountain, water and city in Guilin, and establish a complete protection system from the protection of urban morphology, urban planning, historical gardens to the protection of water system around the city.

The principles of integrity, authenticity, protogenesis, diversity and suitability are applied to the protection and utilization of ancient water systems. The protection of historical space system can be divided into four levels. Firstly, the principle of integrity is highlighted in the protection of historical and cultural heritage. Secondly, the regionality and uniqueness of urban landscape should be highlighted in the aspect of landscape environment. Then the style and features of the ancient water system should be emphasized in the spatial structure. Finally, the integration of mountain, water and city should be highlighted in urban form. In a word, the reconstruction and restoration of water system means to connect the history of two rivers and four lakes with the historical context of Lijiang River and Taohua River. In this way, the unique water system landscape of historical culture and natural waterscape is formed. 


\subsection{Continuation of the historical form and function of the water system around the city}

The nodes are connected. The water system around the city appeared in Song Dynasty and preserved till now. In the connection and restoration of urban water system, the planning of moat in Song Dynasty was taken as the basis, and the existing water system was used as the basis to connect the inner lake with Lijiang River and Taohua River. The specific measures are to rebuild the Mulong Lake, which has been landfilled in the process of urban expansion, and connect it with Lijiang River and Taohua River, and form a living water system. After the completion of the water system, the total water surface area and water volume of the "four lakes" have increased. The total water surface area and water volume increment of "four lakes" are shown in Table 1.

Table 1. Growth table of water area and water volume of "four lakes".

$\begin{array}{ll}\text { Time } & \begin{array}{l}\text { Total water } \\ \text { surface area }\end{array}\end{array}$

Before
rectification $\quad 34.80 \mathrm{hm} 2 \quad 52 \mathrm{hm}^{3}$

After
renovation $\quad 38.59 \mathrm{hm} 2 \quad 78.24 \mathrm{hm}^{3}$

Sludge removal and sewage interception. In order to restore the historical function of the ancient water system, it is necessary to deal with the pollution of the existing water system so as to restore its irrigation, protection, transportation and sightseeing functions. The first thing to be done is to clear the silt accumulated over the years. It is a huge project to remove the accumulated sludge over the years. The dredging project, which began in 2000 , removed 60,000 cubic meters of silt over a sixmonth period. For storm drains that discharge directly into the lake, the pipe lines should be reconstructed and connected to other new storm drain systems to minimize the pollution to the lake. The amount of sewage interception works is shown in Table 2. The importation of living water allows for the formation of a living water system and a more stable ecological water environment. It takes about 7-10 days for water to flow in from the source and then out of the outlet. Thus, the ecological environment of "two rivers and four lakes" would be restored and a proper water circulation system would be constructed.

Table 2. Quantity of sewage interception works.

Place Pollution interception Quantities
project
Gui Lake $\begin{aligned} & \text { Sewage intercepting } \quad 5376.24 \mathrm{~m} \\ & \text { pipeline }\end{aligned}$

Inspection well

Rainwater well

Drop well

Yiwu Road pumping

1 station

$\begin{array}{lll}\text { Rong } & \text { A sewage pipe } & 1795 \mathrm{~m} \\ \text { Lake and } & & \\ \text { Shan } & & \\ \text { Lake } & \text { Rain pipe } & 3310 \mathrm{~m}\end{array}$

Inspection well

Valve well

Rainwater well

10

\subsection{Integration of historical and cultural resources and continuation of historical context.}

From the Song Dynasty to the modern times, many historical sites have been formed around the water system. The historical relics are scattered around the water system without a coherent tourist route to connect them, and the historical culture were not effectively disseminated. Therefore, the construction of Mulong Lake is of great significance. It connects two rivers and four lakes into a living water system, and its waterfront route integrates fragmentary historical sites. There are ruins of Dongzhen Gate and Song City Wall in Mulong Lake, and Ancient South Gate, Huangtingjian Boat Place and Ancient Banyan Tree in Rong Lake and Shan Lake, all of which reflect the development and prosperity of the ancient times. Now the restoration of these sites and their ornamental use will enable visitors to understand the history and enhance their awareness of the protection of historical sites. In addition to the restoration of the existing historical sites, some ancient architectural 
communities and scenic spots with the architectural flavor of the Song Dynasty have been built to enrich the historical atmosphere around the water system and continue the historical context. See Table 3 for historical sites and imitation Song Dynasty buildings and scenic spots.

Table 3. Table of historical sites and imitation Song Dynasty buildings and scenic spots.

\begin{tabular}{|c|c|c|}
\hline Type & Place & Name \\
\hline \multirow[t]{5}{*}{$\begin{array}{l}\text { Historical } \\
\text { site }\end{array}$} & $\begin{array}{l}\text { Mulong } \\
\text { Lake }\end{array}$ & Dongzhenmen \\
\hline & & $\begin{array}{l}\text { Song Dynasty City } \\
\text { Wall }\end{array}$ \\
\hline & $\begin{array}{l}\text { Rong Lake } \\
\text { and Shan } \\
\text { Lake }\end{array}$ & Ancient South Gate \\
\hline & & Ancient Banyan Tree \\
\hline & & $\begin{array}{l}\text { Huangtingjian Boat } \\
\text { Place }\end{array}$ \\
\hline \multirow{10}{*}{$\begin{array}{l}\text { Architectur } \\
\text { al complex } \\
\text { and scenic } \\
\text { spot of } \\
\text { imitation } \\
\text { Song } \\
\text { Dynasty }\end{array}$} & Mulong & Fansong Street \\
\hline & & $\begin{array}{l}\text { Imitation of Song } \\
\text { City }\end{array}$ \\
\hline & & Banbian Street \\
\hline & & Mulong Bridge \\
\hline & & $\begin{array}{l}\text { Wooden Dragon } \\
\text { Tower }\end{array}$ \\
\hline & & $\begin{array}{l}\text { Night Mooring of } \\
\text { Mulong }\end{array}$ \\
\hline & & $\begin{array}{l}\text { Shallow Bridge Fish } \\
\text { Shadow }\end{array}$ \\
\hline & & Listen to Hexuan \\
\hline & & $\begin{array}{l}\text { Ancient Mulong } \\
\text { Ferry }\end{array}$ \\
\hline & & Ancient Post Road \\
\hline
\end{tabular}

\subsection{The restoration of historical spatial pattern of water system around the city}

In order to protect the historical features of the water system around the city, it is necessary to weaken the commercial trade around the city, move out the buildings that have great influence on the historical features, and strengthen the construction of public space. The volume and height of the new buildings should not be too large or too high, which cannot affect the overall historical features of the two rivers and four lakes, and keep in harmony with the surrounding environment. It is forbidden to build too high buildings near the lake, which will affect the overall landscape of the water system around the city. Even if the large-scale Ronghu hotel can be retained, the design of its sloping roof with uneven height reduces the sense of volume. In addition, the plant cover is also suitable for the surrounding environment.
According to the principle of restoring the historical spatial pattern of the water system around the city, the style, architecture and color of the street buildings around the water system are controlled. So that the local characteristics and historical features can be fully reflected, and the historical spatial pattern of the water system around the city can be reconstructed.

\subsection{The preparation of historical heritage protection plan}

Taking the water system around the city as the core, the relationship between historical relics, landscape environment and ancient water system protection is established. The identifiability of ancient water system needs to be strengthened, and the control plan of historical features should be compiled [4].

Based on the moat in Song Dynasty, the cultural characteristics, place characteristics and life characteristics of the water system around the city are restored. The affinity between water system and surrounding environment can be restored to achieve the ideal state of beautiful scenery in the city. The buildings around the water system should adapt to the site conditions, be consistent with the theme of the scenic spot, and be suitable for the atmosphere of the place. The form, color and carved windows of the buildings are all based on the history of the ancient water system and echo with the history. The historical and regional characteristics of the site should be maintained, and the historic nature of the ancient water system environment should be strengthened to reappear the historical spatial pattern of the water system.

The relevant protection policies are formulated to protect historical buildings. The purpose of formulating relevant protection policies is to sort out the history of the water system, improve the historical spatial pattern, and protect the sculptures, sketches and pavilions around the water system. Under the principle of ensuring the authenticity, some historic sites should be repaired as necessary.

\subsection{Continuation of cultural customs and preservation of historical memory}

The water system around the city has always been the gathering place of literati and poets. The ancient literati wrote poems here and sighed at the beautiful scenery at that time. From the Sun and Moon Twin Towers and Bosom Friend Platform of Shan Lake to the Ancient South Gate of Rong Lake and the thousand-year-old banyan trees at Huangtingjian's Boat, all reflect the strong cultural atmosphere of this place. In the process of cultural protection, the local traditional culture is reflected through sculptures, sketches and reliefs, and the historical culture is integrated into the design of waterfront landscape.

Continuing cultural customs. In traditional festivals such as the Dragon Boat Festival, Dragon Boat Racing and other activities will be held regularly, and traditional fishing activities such as Fishermen and Osprey will also 
be displayed. The historical and cultural activities and traditions of a region are the soul of its history and culture. The continuity protection of life characteristics is also an important part of the protection that cannot be ignored. It embodies the living habits, cultural characteristics, features and customs of that era. It is of irreplaceable importance and also an important basis for interpreting local history.

\section{Summary}

As an ancient water system of Guilin, the water system around the city has a lengthy history since the Song Dynasty. Even today, it still possesses high historical, social and human values. Therefore, it is necessary to rehabilitate the peri-urban water system based on the concept of preserving and renewing the historical legacy. The water system around the city is an integral part of urban planning. Due to its historical integrity, richness and complexity of ecological issues, it requires appropriate measures to address the situation. The concept of historical heritage landscape protection and renewal is used to improve the organization system of historical space. The continuation of the historical form and function of the water system space around the city is also based on this concept. Similarly, the integration of historical and cultural resources and the restoration of historical spatial pattern of water system are also based on this concept. In this way, a clear historical context is formed, and the regional characteristics of the city are also highlighted. Preparing a historic preservation plan to continue cultural practices can effectively preserve the authenticity of life and recreate the historic appearance of the water system. By protecting and regenerating historical sites and landscapes, an ideal environment with a wealth of history and culture, sound infrastructure and suitable living conditions can be established, which also creates a regional identity and character of the city.

Acknowledgements: National key R \& D plan (2019YFC0507503)

\section{References}

1. Minkang R. Study and Discussion on the planning and layout of two rivers and four lakes in Guilin. J. Water conservancy planning and design, 9 (2016):78,112 .

2. Bingze L,Liangchu L. Study on the Landscape Construction and Development of Guilin in Song Dynasty. J.Housing Science,12 (2019):66-70.

3. Kehong H. Historic Waterway Preservation: A Case Study of Guilin's “Two Rivers, Four Lakes" Plan/Huang Kehong. J.Planners, 11 (2019)

4. Dazhi G,Huarui W, and Yiran C. Study on the renewal strategy of the Ring Parks around Hefei City from the perspective of "urban double maintenance". J.Journal of Qingdao University of Technology,11 (2019)

5. Xiao W. Analysis on the impact of urban water system transformation on Urban Landscape -Taking Guilin "two rivers and four lakes" project as an example. J.Residential and Real Estate,(2016)

6. Yi Z. Landscape regeneration of urban historical remains. J.Shanxi architecture,12(2011):16-17. 